\title{
An Investigation of Tourism and social media As the Key Instruments in Market Economy and Business Activity
}

\author{
Ariet MALAJ ${ }^{1 *}$, Rezart DIBRA $^{2}$ \\ 1,2University College of Business, Tirana, Albania. \\ Email: ariet_malaj@hotmail.com¹, rezartdibra@yahoo.com² \\ ${ }^{*}$ Corresponding Author
}

\author{
Received: 12.08.2021 Accepted: 29.10.2021 Published: 02.12.2021 DOI: 10.47750/QAS/22.185.25
}

\section{Abstract}

\begin{abstract}
Tourism is a business activity as an industry and an important growth driver for the economy and social progress of a country. Therefore, it brings a tremendous economic value for a country. It impacts several industries directly or indirectly. It is also one of the most important areas of employment and foreign exchange income of a country. The study aimed to scrutinize the significance of social media in tourism for a country in terms of its impact on social and economic activities. For this purpose, in the study a library research method was adapted. The data were analyzed via Content Analysis Table- Chi Square (Hi-square): Test of Pearson Coefficient. The findings have revealed that tourism is generally regarded as the act of travelling to a different location, for either business or pleasure purposes for at least 24 hours, but for no longer than one year. Tourism involves a round trip, rather than travel in one direction only. With this in mind, the tourism industry refers to all aspects of the service industry that cater to tourists. Being one of the "mega trends" that has significantly impacted the tourism system, the role and use of social media in travelers' decision making and in tourism operations and management have been widely discussed in tourism and hospitality research.
\end{abstract}

Key words: Tourism, social media, market economy, business activity, social media

\section{Introduction}

Social media can be defined as a "group of Internet-based applications .Today there are many different types of social media (Kaplan \& Haenlein, 2010; Perakakis, Trihas, Venitourakis, Mastorakis, \& Kopanakis, 2016): social networking sites (e.g. Facebook, Linkedln), social blogging (e.g. Tumblr) or microblogging (e.g. Twitter), social review sites (e.g. TripAdvisor, Yelp, FourSquare), image sharing sites (e.g. Instagram, Pinterest), video hosting sites (e.g. YouTube, Vimeo), discussion sites (e.g. Reddit, Quora), virtual social worlds (e.g. Second Life), virtual game worlds (e.g. World of Warcraft) social bookmarking and voting sites (e.g. Delicious, Digg), sharing economy platforms (e.g. Airbnb, Pantheon, Kickstarter), and social knowledge sharing sites (e.g. Wikipedia, Wikitravel). In recent years, human interaction has been greatly facilitated through all these social media (Lange-Faria \& Elliot, 2012; Trihas, Perakakis, Venitourakis, Mastorakis, \& Kopanakis, 2013). To get a picture of the popularity of social media, active social media users have reached 3.80 billion in January 2020 (recording an increase of 9,2\% over the previous year), with 3.75 billion of them accessing these platforms through their mobile devices (Hootsuite, 2020).

Social media has changed every single aspect of our lives, including the way we consume. These developments have significantly affected businesses mainly through enabling new marketing strategies. Tourism, being one of the most vibrant sectors of the global economy, is undoubtedly a part of all these. Merging social media and tourism marketing will lead to excellent results for your business. Here we have gathered information about the essentials of social media in tourism marketing: what is the role of it and how it can be effectively used. Social media impact on tourism is seen in the ways people research before going on a trip. Now people are encouraged to share their travel experiences. Thus, social media has transformed the way people make decisions. People build their trust in a tourism agency based on the reviews of the others.

Customer service is another essential aspect of the tourism industry that has changed with social media. Now brands and businesses can reach their customers directly through social media. When people are unsatisfied with a tourism service, they can call the companies to account for that. Thus, solving the problems of the customers in the kindest ways will lead to a better reputation for a company. Social sharing might be the most significant factor that affected the tourism industry. Social media enables especially young people to share the most significant memories from their travels with a vast audience. Tourism companies should know that this is a more powerful way of attracting new travelers than simple advertisements and encourage people to share their real experiences online.

As seen above, the rise of social media led to the development of two-way communication between agencies and customers and customers to customers. To benefit from this impact of social media on the tourism industry, turning to social media is vital for a tourism agency. User-generated content is one of the best ways to get people to engage with your business. Influencer marketing will help a lot to make your business visible among the others. After specifying the target location and audience, one can get in touch with tourism influencers and experts.

Tourism marketing may sometimes be challenging and 
expensive particularly when attracting both national and international tourists. Therefore, marketers need to fully understand their customers' needs and desires so that they can devise an appropriate marketing plan. Tourism contributes a lot to a country's GDP. Consequently, countries around the world invest in tourism development and promote attractions to tourists. Appropriate tourism marketing strategies and techniques help countries and organizations achieve their business objectives. Interest in the tourism value of business events, including meetings, conventions, and exhibitions (both trade and consumer shows) has a long pedigree given that almost all major cities now possess impressive convention and exhibition facilities (see Boo, Koh, \& Jones 2008), along with agencies devoted to selling the space and bidding on events (see Kim, Yoon, \& Kim, 2011 on the competitive positioning strategies of event convention centers in East Asia). The first convention bureau in the USA was established as far back as 1896 (Spiller, 2002) and the Destination Marketing Association International traces its origins to 1915 (www. destinationmarketing.org/) as highlighted in the Introduction. Often referred to as the MICE industry, that is, meetings, incentives, conventions and events/exhibitions (Schlentrich, 2008), there is some doubt about the validity of including incentive tours; Fenich (2005) prefers MEEC for Meetings, Expositions, Events and Coventions. Weber and Chon (2002) assessed this sector in Convention Tourism: International Research and Industry Perspectives. Other books on the subject of business-event tourism include those by Davidson and Cope (2003), Davidson and Rogers (2006), Davidson, Holloway, and Humphreys (2009), and Mair (2013).

Some researches explored trends in the convention industry including government's increasing awareness of its economic benefits (Weber and Ladkin, 2004,2008; Jamo, 2021). Review articles have covered convention tourism research (Yoo \& Weber, 2005; Mair 2012) and convention and meeting management research (Lee \& Back, 2005) including the tourism dimension. Lee and Lee (2014) reviewed research articles on exhibitions and discussed themes related to exhibitors in particular. Lee and Palakurthi (2013) conducted research on how constraints influenced exhibition attendance. Mair (2012) reviewed 144 articles from the business-event literature for the period 2000 through 2009; the vast majority of which were published in the Journal of Convention and Event Tourism.

Festivals in society and culture, pertaining to their roles, meanings and impacts, is the best developed discourse, rooted firmly in sociology and anthropology. Festivals and tourism has been reviewed in depth by Getz (2011) in a study that identified the following classical themes pertaining to festivity: myth, ritual and symbolism; ceremony and celebration; spectacle; communitas; host-guest interactions (and the role of the stranger); liminality; the carnivalesque; authenticity and commodification; pilgrimage; and a considerable amount of political debate over impacts and meanings. Festival tourism is a mainstream subject of research (e.g., Anwar \& Sohail, 2004; Donovan \& Debres, 2006; Formica \& Uysal, 1998; McKercher, Mei, \& Tse, 2006; Nurse, 2004; Robinson, Picard,

\& Long, 2004; Saleh \& Ryan, 1993). Occasionally art exhibitions and tourism have been examined (e.g., Mihalik \& Wing-Vogelbacher, 1992). Much of the discourse has been subsumed in the literature on cultural tourism (e.g., McKercher \& du Cros, 2002; Richards, 1996, 2007). Festivals have been examined in the context of place marketing, urban development, tourism and more recently social change (e.g., Picard \& Robinson, 2006a). Some of the growth in festival numbers and variety has been attributed to diaspora (Basu, 2005; Laing \& Frost, 2013), that is the mass-migration of people who carry traditions with them.

The discourses associated with events and tourism and the ontological mapping of event studies have been discussed by Getz (2012a, 2012b). In this paper consideration was given to the theoretical and methodological contributions of various foundation disciplines, along with public policy implications. In Figure 1 below depicts is the way in which event studies now incorporates a wider perspective of event scholarship in which event management and event tourism are situated as foundation blocks for event studies.

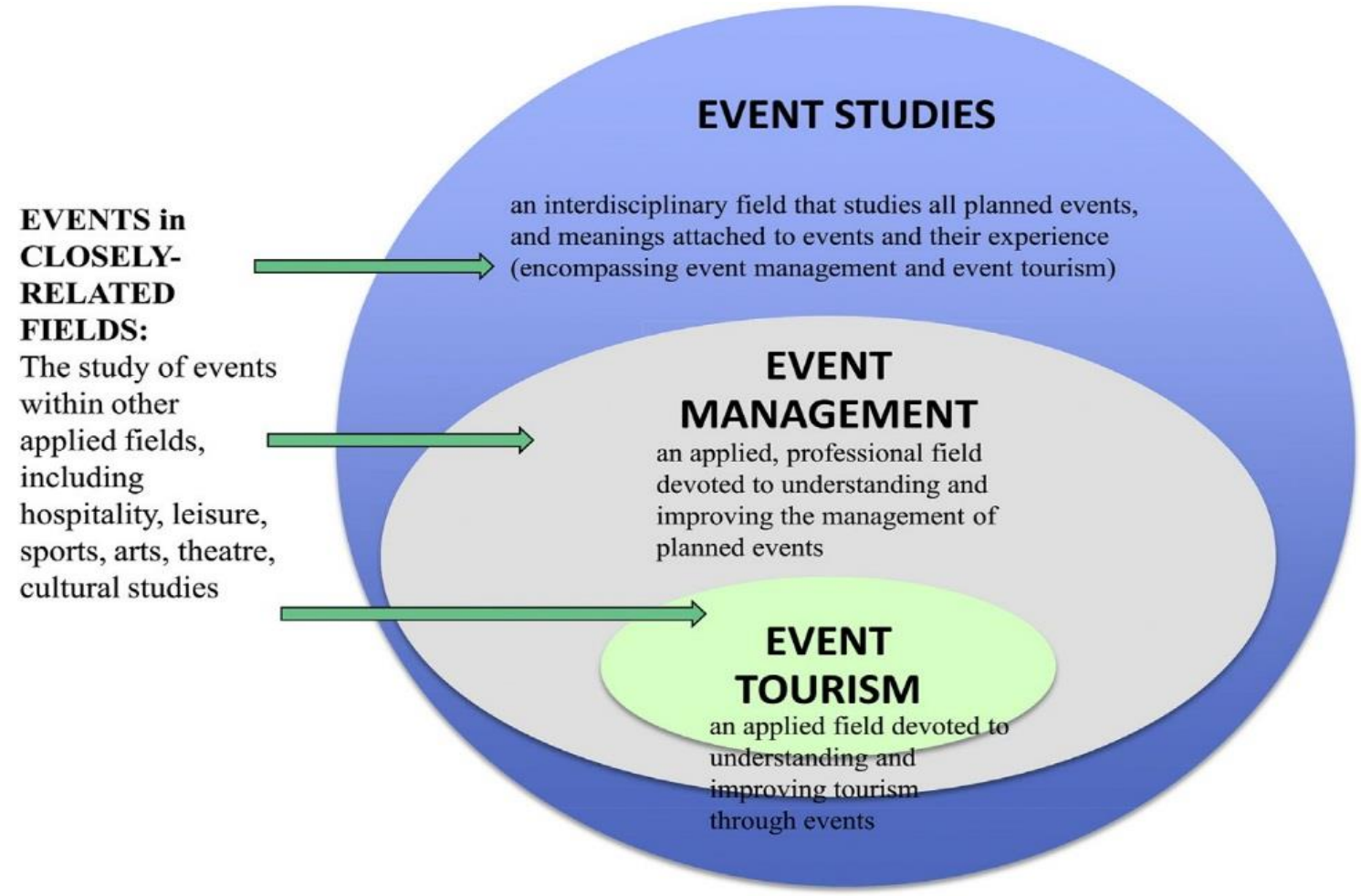

Fig. 1: Event studies, event management and event tourism 


\section{GENERAL MANAGEMENT}

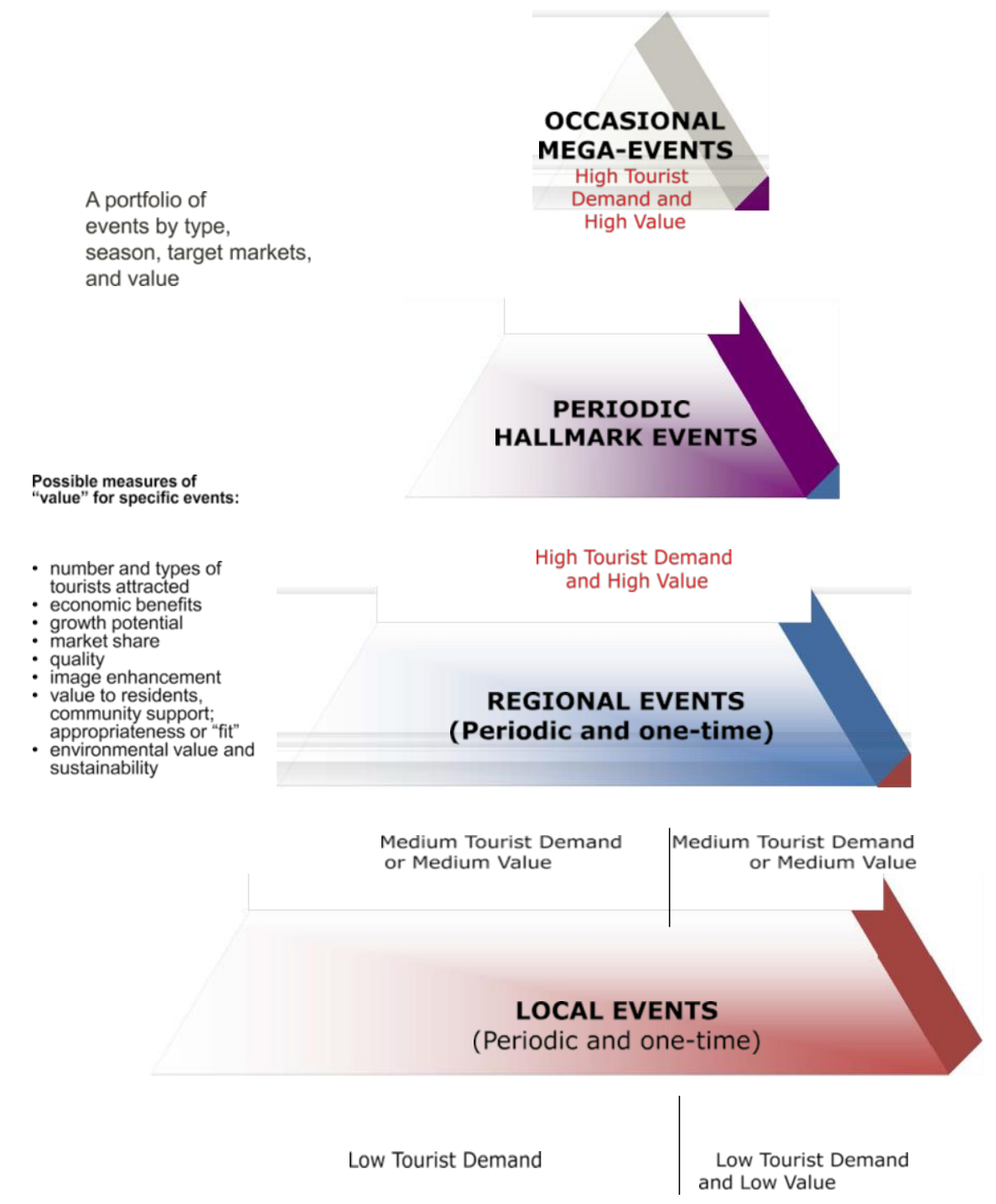

Fig.2: The Portfolio approach

This strategic approach can help shape evaluation, planning, and policy for events. An event-centric perspective on event tourism is discussed, referring to how many events are marketed to attract tourists. The conceptual section concludes with a brief re-view of major trends in the context of propelling and constraining forces, and this helps to explain the phenomenal growth of events and event tourism (Figure 2).

In the figures 1 and 2 above, there is a good combination of tourism strategies and management contribution. 


\section{GENERAL MANAGEMENT}

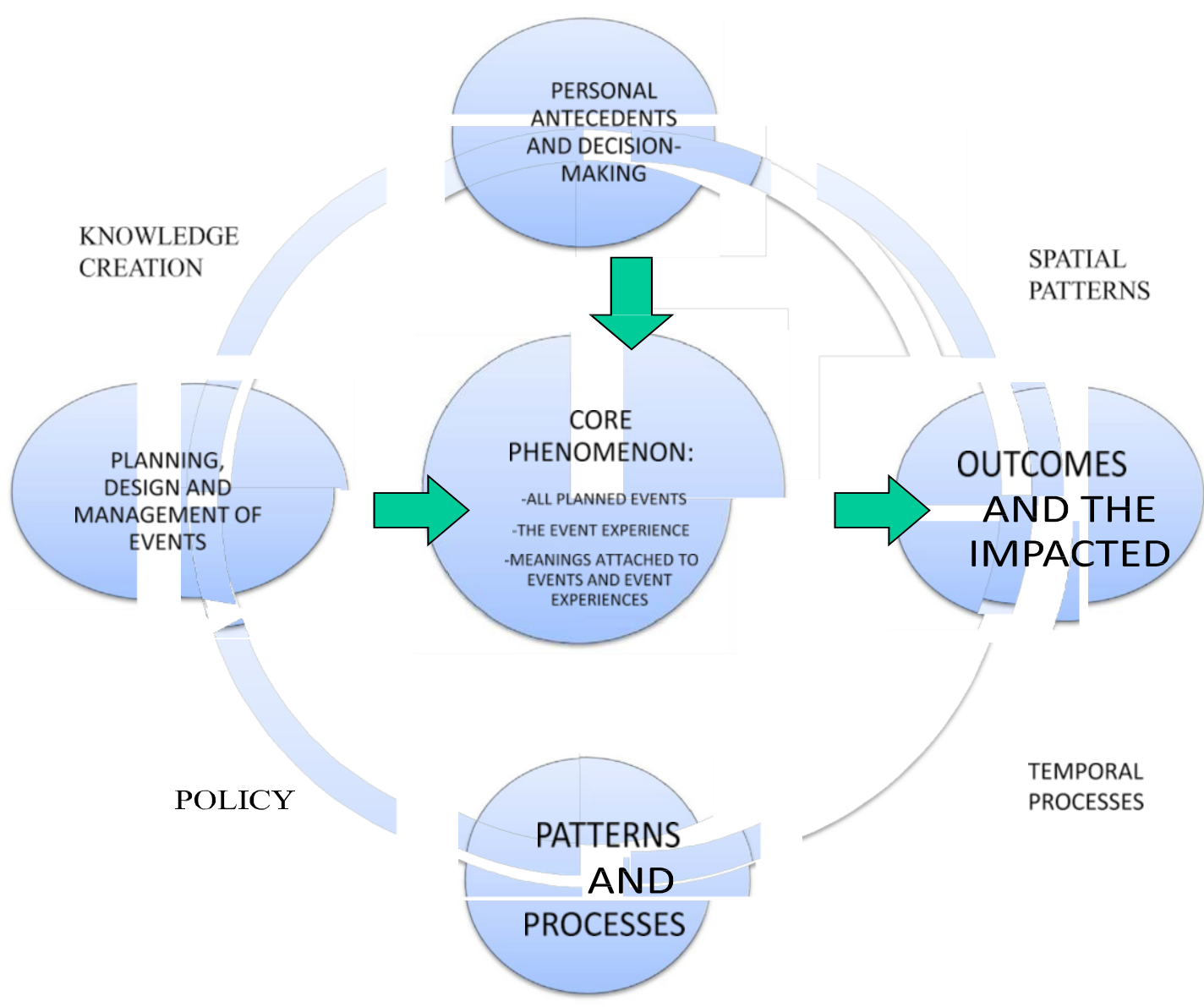

Fig. 3: A framework for studying knowledge on event tourism (Getz, 2005, 2013a).

\section{Methodology}

Ajala.O.A. (2019) in his work on Employment and Income Potentiality of Tourism Development in around the world examined the role of tourism development in socioeconomic development of the region, generating foreign exchange, reducing unemployment and in improving the living standard of the people. The author has focused on Hotel industry, Souvenir, Tour guide, and water transport business.

The legislative framework concerning tourism development underwent several changes between 1992 and 2019. Similar to the series of sectorial and cross-sectoral strategies related to tourism such as the 1993 Law No. 7665 'For the development of priority areas in tourism' (GoA,1993), the implementation of laws was often flawed by delays and lack of monitoring despite ambitious starting points.

Most people think of tourism in terms of economic impacts, jobs, and taxes. However, the range

of impacts from tourism is broad and often influences areas beyond those commonly associated

with tourism. Leaders as well as residents who understand the potential impacts of tourism can

integrate this industry into their community in the most positive way.

1. Economic

2. Environmental

3. Social and cultural

4. Crowding and congestion

5. Services

6. Taxes

7. Community attitude
The methodology used in this paper combines primary data with secondary data. Primary data are obtained through questionnaire, is distributed in different cities in Tourism companies as consolidated market companies and which undoubtedly hold an important part of the economy sector. Secondary data are received from internet.

This paper is based on data obtained from some companies in Albania. The data was analyzed using simple descriptive statistics. We have used the SPSS program for analysis of all the information.

There are 60 companies that are operating in the tourism field. Concretely Albanian Tours, Vas Tours, Tirana Tours etc.

\section{Result of the study}

Businesses operating in the economic environment in Albania that have been studied $80.3 \%$ have been working for over 10 years in Albania. According to the results of the study $60 \%$ of companies have implement social media in their company to publish their offer, concretely the offer in the summer holiday.

In our study we are combination tourism and social media in a chi square table, person coefficient.

We have prepared some question about the tourism activity.

\section{Content Analysis Table- Chi Square (Hi- square): Test of Pearson Coefficient}

The simplest type of contingency table is a table in which each variable has only two levels; this is called the $2 \times 2$ table of contingencies, where the following for these tables will also 


\section{GENERAL MANAGEMENT}

have a special point of analysis. In principle, any number of rows and columns can be used. There may be even more than two variables.

As determined in the theoretical analysis, the Chi Square Test of Pearson Coefficient analyzes whether there is a link between two qualitative variables. As part of the crosstabs procedure, SPSS produces a chart that, like any of the below, includes the Chi Square statistic and its value of importance otherwise known as the Likelihood Ratio. Chi-Square Coefficient Pearson tests whether the two variables are independent.

Statistical (meaning) is quite small (usually Sig $<0.05$ where $5 \%$ is the level of reliability) then we reject the hypothesis that the variables are independent and accept the hypothesis that they have a relation between them.

The selection of questions is made by supporting a logical justification for the relationships that may exist between them and then they are transformed into the resulting tables of the combination of these questions that contain the respective responses that emerge from the program (including the degrees of freedom) as a value of importance. Pearson's Chi-Square statistical analysis in our analysis begins on case 1 and ends on case 10.
The relation between the variables is significant (i.e. variables are dependent) if the value of Sig $<0.05$, and if this value is $>0.05$ we say the variables are independent between them. The alternative of "Chi Square" is the Pearson coefficient based on the maximum length theory.

Let's start by studying the combination of cases. There were 6 selected cases with combinations of their relevance. The combination questions are from the questioners prepared for companies (result of analyses), concretely the combination of questions, and concretely more important questions.

\section{Case 1}

From the first case analysis we see that the value of the ChiSquare static is $=13.401$. This value is statistically significant when $p<0.001$. This value from question processing results to be significant $(p=0.009<0.05)$, indicating that we have a dependency relation between the variable expressed in the question "Are you familiarized with social media?", and with the variable expressed with the question "What is the role of socia media in the number of tourist?", so there is a link between the variables. Variables specifically result in dependence.

\begin{tabular}{|c|c|c|c|}
\hline \multicolumn{5}{|c|}{ Table 1 } \\
CASE 1: CHI-SQUARE TESTS \\
\hline & Value & df & Asymp. Sig. (2-sided) \\
\hline Pearson Chi-Square & $13.401^{\mathrm{a}}$ & 4 & 0.009 \\
\hline Likelihood Ratio & 16.253 & 4 & 0.003 \\
\hline Linear-by-Linear Association & 8.821 & 1 & 0.003 \\
\hline N of Valid Cases & 76 & & \\
\hline
\end{tabular}

Note: a. 5 cells $(55.6 \%)$ have expected count less than 5 . The minimum expected count is 0.67 .

An alternative to the "Pearson Chi Square coefficient" is the Pearson statistical coefficient based on the maximum length theory.

As we said above, the Loss Report test is a statistical test used to compare two models for their averages if they are statistically the same (which is the zero hypothesis) and the other case when they are not the same (alternative hypothesis).

Lynch ratio in our case (Likelihood Ratio) $=16.253$. As in the case of hi-square we will analyze $p$-ne, $p=0.03<0.05$. Variables with this condition result to be dependent.

The used statistical test revealed a significant link between the variables, namely the variables are dependent and the relation between them is justified.

\section{Case 2}

What is the role of tourism in Albanian society? With the question: The role of social media in tourists companies?

The value of the Pearson Chi Square coefficient in the table below is $=4.823$. This value is not significant as $p=0.567>0.05$. This value in the case below is not important because it results not within the appropriate static parameter $(p<0.05)$, indicating that we have no connection between the above variables. The test did not prove satisfactory.

\begin{tabular}{|c|c|c|c|}
\hline \multicolumn{4}{|c|}{ Table 2 } \\
CASE 2: CHI-SQUARE TESTS \\
\hline & Value & df & Asymp. Sig. (2-sided) \\
\hline Pearson Chi-Square & $4.823^{\mathrm{a}}$ & 6 & 0.567 \\
\hline Likelihood Ratio & 5.066 & 6 & 0.535 \\
\hline Linear-by-Linear Association & 0.976 & 1 & 0.323 \\
\hline N of Valid Cases & 76 & & \\
\hline
\end{tabular}

Note: a. 8 cells $(66.7 \%)$ have expected count less than 5 . The minimum expected count is 0.16 .

The Likelihood Ratio is 5.066. This confirms the main hisquare result $=0.535(p=0.535 \& \mathrm{lt} ; 0.05)$ by showing that the variables are not so unrelated, so an acceptable result link cannot be judged.

\section{Case 3}

Are all companies interested for social media? With the question: Have your clients access in social media?
The value of the Pearson Chi Square coefficient in the table below is $=0.387$. This value is not statistically significant since $p=0.534>0.05$ indicating that we have no relation between the above variables. The test did not prove satisfactory.

The Likelihood Ratio is 0.652 and $p=0.419>0.05$. The main Chi-square expression is confirmed, which expresses $(p=$ $0.652>0.05$ ) that the variables are independent where, and in this case as in case 3 , an acceptable result link cannot be considered. 


\section{GENERAL MANAGEMENT}

\begin{tabular}{|c|c|c|c|}
\hline \multicolumn{5}{|c|}{ Table 3 } \\
CASE 3: CHI-SQUARE TESTS \\
\hline & Value & df & Asymp. Sig. (2-sided) \\
\hline Pearson Chi-Square & $0.387^{\mathrm{a}}$ & 1 & 0.534 \\
\hline Continuity Correction $^{\mathrm{b}}$ & 0.000 & 1 & 1.000 \\
\hline Likelihood Ratio $^{\mathrm{N}}$ & 0.652 & 1 & 0.419 \\
\hline Fisher's Exact Test & & & \\
\hline Linear-by-Linear Association $^{-}$ & 0.382 & 1 & 0.537 \\
\hline N of Valid Cases & 76 & & \\
\hline
\end{tabular}

Note: a. 2 cells $(50.0 \%)$ have expected count less than 5 . The minimum expected count is .28

b. Computed only for a $2 \times 2$ table

\section{Case 4}

Are you publishing information in social media? With the question How is the role of social media in the number of tourist receiving?
The value of the Pearson Chi Square coefficient in the table below is $=14,738$. This value is wholly meaningful as $p=0.005$ $<0.05$. We point out that this value in the case below is significant because it results within the static parameter ( $p$ $<0.05$ ), indicating that we have links between the above variables.

\begin{tabular}{|c|c|c|c|}
\hline \multicolumn{5}{|c|}{ Table 4 } \\
\hline & VASE 4: CHI-SQUARE TESTS \\
\hline Pearson Chi-Square & $14.738^{\mathrm{a}}$ & $\mathbf{d f}$ & Asymp. Sig. (2-sided) \\
\hline Likelihood Ratio & 17.738 & 4 & 0.005 \\
\hline Linear-by-Linear Association & 4.393 & 1 & 0.001 \\
\hline N of Valid Cases & 76 & & 0.036 \\
\hline
\end{tabular}

Note: a. 4 cells (44.4\%) expected to count less than 5 . The minimum expected count is 0.71 .

This value is significant when $p<0.001$. In this case it is completely so, so it matched.

The test was completely satisfactory and with a full connection.

The Likelihood Ratio is $=17,738$. The main result Chi Square $(p=0.001<0.05)$ extracts us at the concatenation of the variables are considered dependent.

\section{Case 5}

Do you have a special structure to receive information from other companies.? And the question Do you think the time has to receive information?

The Chi Square statistic value according to Pearson coefficient in the table below is $=0.056$. This value is statistically significant when $p<0.001$. This value is not significant $(p=$ $0.812>0.05$ ), indicating that we do not have a link between the aforementioned variables. The Likelihood Ratio is $=0.109$. The main result Chi Square $(p=0.741>0.05)$ gives us the concatenation of the variables are considered independent, namely we have no relation between the variables.

\begin{tabular}{|c|c|c|c|}
\hline \multicolumn{4}{|c|}{ Table 5 } \\
CASE 5: CHI-SQUARE TESTS \\
\hline & Value & df & Asymp. Sig. (2-sided) \\
\hline Pearson Chi-Square & $.056^{\mathrm{a}}$ & 1 & .812 \\
\hline Continuity Correction $^{\mathrm{b}}$ & .000 & 1 & 1.000 \\
\hline Likelihood Ratio $^{\mathrm{N}}$ & .109 & 1 & .741 \\
\hline Fisher's Exact Test & & & .814 \\
\hline Linear-by-Linear Association & .056 & 1 & \\
\hline N of Valid Cases & 76 & & \\
\hline
\end{tabular}

Note: a. 3 cells $(75.0 \%)$ have expected count less than 5 . The minimum expected count is .05

b. Computed only for a $2 \times 2$ table

\section{Case 6}

Have you had specific reports from the quality of service of hotels and information about Albanian destination? With the question How is the number of tourist that has receive information from social media?

The Chi Square statistic value in the table below is $=0.103$. This value is known to be significant when $p<0.001$. This value is not significant $(p=0.950>0.05)$, indicating that we have no connection between the above variables. 


\section{GENERAL MANAGEMENT}

\begin{tabular}{|c|c|c|c|}
\hline \multicolumn{4}{|c|}{ Table 6} \\
CASE 6: CHI-SQUARE TESTS \\
\hline & Value & df & Asymp. Sig. (2-sided) \\
\hline Pearson Chi-Square & $0.103^{a}$ & 2 & 0.950 \\
\hline Likelihood Ratio & 0.195 & 2 & 0.907 \\
\hline Linear-by-Linear Association & 0.091 & 1 & 0.762 \\
\hline N of Valid Cases & 76 & & \\
\hline
\end{tabular}

Note: a. 5 cells $(83.3 \%)$ have expected count less than 5 . The minimum expected count is 0.04 .

Maximum length ratio is 0.195 .Chi - square $(p=0.907>$ $0.05)$. The variables have no relation (are independent)

\section{Discussion and Conclusions}

Albania is a country with scarce tourism offer from the superstructure point of view. Family hotels with limited capacities does not allow for increases in the number of guests and an extensive role of tourism in specific regions or communities. Though a country where a variety for of tourism might take place the reduced number of hotels and scarce capacities does not allow for big groups of tourists which in their spur might induce the communities a more proactive approach to Tourism and Tourism related activities.

The aim of this article has been to analyze the governance dynamics and challenges of tourism development in Albania, with a particular focus on policy-making aspects of the sector.

If Albania is adamant about its tourism ambitions and willing to turn it into a key driver for economic development, actions to improve the governance of the sector are required on numerous levels. According to the correlation there are some conclusions:

There is a good correlation because the variables are independent in the dual question that we have selected:

Many hotels, especially those along the seashores of Albania are built early solely as beach hotels. They do not offer other opportunities for groups that want to spend days out of summer season. They have not diversified the offer and therefore they cannot employ people out of the season. The seasonal workers either are not often registered at all, or are registered as part time employees without any effect on the overall employment of the country. Furthermore, the seasonal workers often do not see their careers in Tourism industry, which is a factor why Tourism might be not strongly connected with the employment in the country. The investments should contribute to increase the accommodation capacities or improve the existing ones.

Concretely in this correlation: Have you had specific reports from the quality of service of hotels and information about Albanian destination? With the question How is the number of tourist that has receive information from social media? The variables are independent. Independent variables are variables that are manipulated or are changed by researchers and whose effects are measured and compared. The independent variables are called as such because independent variables predict or forecast the values of the dependent variable in the model.

First, it is important that the tourism governance process is realistic and acknowledges that the increasing tourism figures have not translated into actual growth (contribution to the gross value added). The tourism development narrative in Albania needs to be amended along with the ways that success and progress in the sector are measured.

Albania as a 'tourist destination' is a positively evolving reality, as growth trends have shown over the years. The current picture of the sector does not, however, portray an accurate picture of the sector's dynamics and what its future projections may be for a number of reasons including the following:

Inevitably the rise of event tourism is generating a greater need for accountability, transparency, and comprehensiveness in evaluation of policies, strategies, investments and interventions. This applies to bidding, developing a comprehensive portfolio, and construction or replacement of venues. Researchers have made great strides in developing theory and methods for non-economic impact topics, most recently by stressing social capital, use and non-use values, footprint calculations and taking a multistake holder approach. But full cost and benefit evaluations are rare and it is exceptional to see proper consideration of opportunity costs or key externalities like security and infrastructure costs for mega events. Long-term evaluation of leveraging and legacy effects is needed. Key in- dictators are being developed to both reflect triple-bottom-line thinking and encourage standardization of impact assessments and forecasts. A primary need is to focus attention on the bigger evaluation questions of what an event is worth, how to value events within a portfolio, and the relative value of permanent versus one-time events.

Finally, it is pertinent to conclude with a focus on education for event tourism. Event management education is now well established in many countries, but it is inevitable that event tourism will find a place of its own. This is in part a function of the increasing number of jobs specific to event tourism indicative of the potential drop in student demand for tourism and value in combining tourism and closely related studies like events more closely. The synergistic effects of these new (or perhaps re-invented) mergers offer students more choices and bring applied management fields closer together as advocated by Getz (2014).

The using of social media the touristic operators is very important (Getz 2019) because the information is fast and very commode. The society that use the social media has a good progress in the tourism market.

\section{References}

[1] Bahar O., Kozak M. (2008). Tourism Economics. New York: Nova Science Publishers, Inc.

[2] Balaguer, J., \& Cantavella-Jordá, M. (2002). Tourism as a longrun economic growth factor: the Spanish case. Applied Economics, 34(7), 877-884. doi:10.1080/00036840110058923

[3] Brida J. G., Barquet A. and Risso A. W. (2010). Causality between Economic Growth and Tourism Expansion: Empirical Evidence from Trentino - Alto Adige, TOURISMOS: An International Multidisciplinary Journal of Tourism 5(2), 87-98.

[4] Brida, J.G., Carrera, E.J.S. and Risso, W.A. (2008). Tourism's Impact on Long-Run Mexican Economic Growth. Economics Bulletin, 3, 1-10.

[5] Carrera E. J., Brida J. G., Risso A. W., (2008). Tourism's Impact on Long-Run Mexican Economic Growth, Economics Bulletin 3(21), 1-8.

[6] Crompton, J. L., Lee, S., \& Shuster, T. J. (2001). A Guide for Undertaking Economic Impact Studies: The Springfest Example. Journal of Travel Research, 40(1), 79-87. doi:10.1177/004728750104000110 


\section{GENERAL MANAGEMENT}

[7] Dwyer L., Forsyth P., Spurr R. (2004). Evaluating Tourism's Economic Effects: New and Old Approaches, Tourism Management 25, 307-317.

[8] Fine, D., Wamelen, A.V., Lund, S., Cabral, A., Taoufiki, M., Dorr, N., Leke, A., Roxburgh, C., Schubert, J. and Cook, P. (2012) Africa at Work: Job Creation and Inclusive Growth.

[9] Granger, C. W. J. (1969). Investigating Causal Relations by Econometric Models and Cross-spectral Methods. Econometrica, 37(3), 424. doi:10.2307/1912791

[10] Granger, C. W. J., \& Newbold, P. (1974). Spurious regressions in econometrics. Journal of Econometrics, 2(2), 111-120. doi:10.1016/0304-4076(74)90034-7

[11] Jamo, I. A. (2021). Democracy, local government and infrastructural development: a study of Zaria local government (LG) in Kaduna state Nigeria. International Journal of Education, Technology and Science1(3), 46-60.

[12] Yevheniia M. Provorova; Tetiana O. Harasym; Andriana R. Zubryk; Olha V. Ladyka; Valentyna A. Shepitchak. "Formation of foreign language professionally oriented competence of future foreign language teachers with the use of electronic educational resources". Journal for Educators, Teachers and Trainers, 11, 1, 2020, 1-12. doi: 10.47750/jett.2020.11.01.001

[13] Johansen, S. (1991). Estimation and Hypothesis Testing of Cointegration Vectors in Gaussian Vector Autoregressive Models. Econometrica, 59(6), 1551. doi:10.2307/2938278

[14] Kadiyali, V., \& Kosová, R. (2013). Inter-industry employment spillovers from tourism inflows. Regional Science and Urban Economics, 43(2), 272-281. doi:10.1016/j.regsciurbeco.2012.07.006

[15] Lütkepohl, H. (1985). COMPARISON OF CRITERIA FOR ESTIMATING THE ORDER OF A VECTOR AUTOREGRESSIVE PROCESS. Journal of Time Series Analysis, 6(1), 35-52. doi:10.1111/j.1467-9892.1985.tb00396.x

[16] McCatty, M. and Serju, P. (2019) Tourism, Economic Growth and Employment. Bank of Jamaica, Kingston.

[17] Nowak, J.-J., Sahli, M., \& Cortés-Jiménez, I. (2007). Tourism, Capital Good Imports and Economic Growth: Theory and Evidence for Spain. Tourism Economics, 13(4), 515-536. doi: $10.5367 / 000000007782696113$

[18] Onder K., Durgun A. (2018). Effects of tourism sector on the employment in Turkey: An econometric application, Retrieved from http://epoka.edu.al/new/icme/26.pdf (accessed 15.02.2018.)

[19] Phillips, P. C. B. (1986). Understanding spurious regressions in econometrics. Journal of Econometrics, 33(3), 311-340. doi:10.1016/0304-4076(86)90001-1

[20] Vellas, F., (2019). The Indirect Impact of Tourism, Third Meeting of T20 Tourism Ministers Paris, 25 October, 2019. [18] Tourism highlights, Edition, UNWTO Madrid

[21] World Travel \& Tourism Council (WTTC): Travel \& Tourism Economic Impact 2019- Albania 